\title{
THE SUMMER MEETING IN AMHERST
}

The American Mathematical Society held its sixty-ninth summer meeting at the University of Massachusetts in Amherst, Massachusetts from Tuesday through Friday, August 25-28, 1964.

The forty-second Colloquium was presented by Professor Charles B. Morrey of the University of California. The title of the lectures was Multiple integrals in the calculus of variations. He was introduced at the initial lecture by Professor J. L. Walsh. At the remaining lectures, Professors Antoni Zygmund, Herbert Federer, and W. T. Reid presided.

By invitation of the Committee to Select Hour Speakers for Summer and Annual Meetings, there were two addresses.

Professor Arthur Sard of Queens College of the University of the City of New York spoke on Function spaces. He was introduced by Professor R. Creighton Buck.

Professor John Stallings of Princeton University spoke on The foundations of polyhedral topology. Professor J. G. Hocking introduced the speaker.

There were twenty five sessions for contributed papers, at which 156 papers were presented.

The following members were very helpful in accepting the chairmanship of sessions for contributed papers: Professors R. D. Anderson, M. G. Arsove, R. H. Bruck, W. W. Comfort, J. H. Curtiss, Dr. D. A. Edwards, Dr. Melvin Dresher, Professor F. A. Ficken, Dr. A. S. Galbraith, Michael Goldberg, Professors Theodore Hailperin, P. C. Hammer, Simon Hellerstein, Erik Hemmingsen, F. Burton Jones, N. H. McCoy, S. G. Mrowka, R. S. Pierce, G. Y. Rainich, W. H. Ruckle, R. T. Seeley, M. F. Smiley, W. R. Wasow, and Dr. H. H. Wicke.

Several organizations cooperated in holding their meetings on the same campus and at approximately the same time as the Society. These included the Mathematical Association of America, August 24-26; Pi Mu Epsilon, August 25-26; Mu Alpha Theta, August 26; Society for Industrial and Applied Mathematics, August 26; Institute of Mathematical Statistics, August 26-29.

Social and recreational events included an all day excursion to Old Sturbridge Village on Wednesday, August 26. SIAM followed a tradition, which had lapsed in the very recent past, of holding a beer party on Wednesday evening. The Gymnasium of Amherst College was the chosen location. 
The Committee on Arrangements consisted of A. E. Anderson, chairman, R. H. Breusch, H. G. Jacob, T. Norvig, R. W. Wagner, and L. C. Lavallee, all appointed, and H. L. Alder, E. Pitcher, G. L. Walker ex officiis.

The Council met on Tuesday, August 25, at 5:00 P.M.

The Secretary announced the election of the following one hundred and seventy-three persons to ordinary membership in the Society:

Adams, Sterlin N., Tennessee A and I State University;

Adkins, A/2c Carl J., U. S. Air Force, Box 602, 462nd Supron, Larson Air Force Base, Washington;

Akcoglu, Mustafa A., Brown University;

Anastasio, Salvatore, New York University;

Andersen, John E., System Development Corporation, Brunswick, Maine;

Andrews, George E., University of Pennsylvania;

Anson, Dennis, University of Florida;

Ash, Robert B., University of Illinois;

Bajsanski, Bogdan, Ohio State University;

Bell, Frederick H., Canton Area Technical School, Canton, Ohio;

Berin, Al., Hughes Aircraft Company, Culver City, California;

Biggs, John H., University of Illinois;

Bolger, Robert E., Fairfield, University;

Boyd, Arthur, Campbell-Ewald Company, Detroit, Michigan;

Boynton, Charles E. IV, Basic Systems Incorporated, New York, New York;

Brady, Allen H., National Bureau of Standards, Boulder, Colorado;

Brualdi, Richard A., Syracuse University;

Cain, Bryan E., University of Wisconsin;

Caslin, James C., Aerospace Research Laboratories, Wright Patterson Air Force Base, Ohio;

Chetelat, Guy F., California Dental Service, San Francisco, California;

Clark, William E., Tulane University;

Coleman, Bernard D., Mellon Institute, Pittsburgh, Pennsylvania;

Crenshaw, James A., University of Illinois;

Criner, Oscar H., United Research Services, Burlingame, California;

Cummings, John W., Standard Packaging, Brooklyn, New York;

Currin, Marjorie L. (Mrs. H. L.), General Electric Company, Daytona Beach, Florida;

Cusick, Thomas W., University of Illinois;

Czarnec, Walter J., Framingham State College,

Der, Ernest J., North American Aviation, Downey, California;

Diekhans, Herbert H., University of Illinois;

Dionne, Jean-Paul J., Washington University;

Donahue, Michael A., Radio Corporation of America Service Company, Patrick Air Force Base, Florida;

Duncan, Ian M., DeVry Technical Institute;

Dyche, Chester W., Tuskegee Institute;

Eiss, Joseph J., New York University;

Ellefson, John R., Sperry Utah Company, Salt Lake City, Utah;

Engelman, Laszlo, University of Southern California; 
Finlayson, Henry C., University of Manitoba;

Forrest, Robert G., Frederick College;

Fukuda, Noriko H. (Mrs. Y.), 1677 Westholme Ave., Los Angeles, California 90024;

Gantos, Richard L., Michigan State University;

Gasper, George, Jr., Wayne State University;

Gatterdam, Ronald W., Autonetics, Anaheim, California;

Gebert, James R., 2949 N. 68th Street, Milwaukee, Wisconsin 53210;

Gola, Aristide S., Douglas Aircraft Company, Santa Monica, California;

Gover, Eugene H., Brandeis University;

Gratiaa, Marceline C., Winona State College;

Greechie, Richard J., University of Florida;

Green, Marvin D., University of Cincinnati;

Grossman, Fred, Columbia University, Hudson Laboratories;

Grover, Shamsher S., The M. W. Kellogg Company, New York, New York 10017;

Gruska, Gregory F., University of Detroit;

Guinn, Theodore, Douglas Aircraft Company, Santa Monica, California;

Guthery, Scott B., Miami University;

Haggstrom, Gus W., University of Illinois;

Hagis, Peter, Jr., Temple University;

Hannigan, John F., Jr., Florida State University;

Harden, Stephen D., University of Cincinnati;

Harris, Bernard, University of Wisconsin;

Hersh, Reuben, University of New Mexico;

Hong, Dang X., George Peabody College for Teachers;

Hsieh, Po-Fang, University of Minnesota;

$\mathrm{Hu}$, Shu-Shih, Tulane University;

Husch, Lawrence S., Florida State University;

Jain, Mahendra K., Bihar Institute of Technology, Sindri, Dhanbad, India;

Jancewicz, Fred A., General Electric Company, Ithaca, New York;

Johnson, James J., Auburn University;

Jones, Dallas J., 1129 Sewanee Road, Nashville, Tennessee 37220;

Juola, Robert C., Michigan State University;

Kasarda, Andrew J., Shippensburg State College;

Katsanis, Theodore, National Aeronautics and Space Administration, Cleveland, Ohio;

Katz, Victor J., Brandeis University;

Keeling, John H., DeVry Technical Institute;

Kellogg, Charles N., Louisiana State University;

Kennedy, Lee H., Texas Technological College;

Kenner, Paul M., University of Texas;

Knighten, Carol M. (Mrs. R. L.), Massachusetts Institute of Technology;

Koenen, William B., 1800 Laurel Ave., St. Paul, Minnesota 55104;

Krolikowski, Thomas, Allis-Chalmers Manufacturers, West Allis, Wisconsin;

Laison, Diane, University of Pennsylvania;

Lavalle, Irving H., Harvard Business School;

Lawrence, Harold G., Oregon State University;

Levinson, Henry W., New York University;

Levy, Joel, National Bureau of Standards, Washington, D. C.;

Loane, Edward P., Wagner Associates, Paoli, Pennsylvania; 
Low, Marc E., University of Illinois;

Luft, Philip E., Box 271, Springer, New Mexico;

McAfee, Jesse S., Pennsylvania Military College;

McCall, John T., Jr., University of Wisconsin;

McDaniel, Harold G., Park College;

McGehee, Earl E., Jr., University of South Carolina;

McGehee, Ralph M., New Mexico Institute of Mining and Technology;

McKay, Donald O., University of Western Ontario;

McKissick, Robert J., Tulane University;

McPherson, James C., Ballistics Research Laboratories, Aberdeen Proving Ground, Maryland;

MacGillivray, Archibald D., Massachusetts Institute of Technology;

Meissner, Loren P., Lawrence Radiation Laboratory, University of California, Berkeley, California;

Miao, Ling S., Cornell University;

Millham, Charles B., Iowa State University;

More, Trenchard, Jr., Yale University;

Morez, Nick S., University of Colorado;

Moser, David B., Lockheed-Georgia Company, Marietta, Georgia;

Munoz, Diego R., Smythe Research Associates, San Diego, California 92123;

Murray, Spencer B., Mississippi State University;

Nyhoff, Larry R., Calvin College;

O'Neill, John D., University of California, Berkeley;

Oswald, Karl, DeVry Technical Institute;

Page, Stanley S., University of Washington;

Pal, Alexander, Bell Telephone Laboratories, Murray Hill, New Jersey;

Pickett, Harry E., California Research Corporation, Richmond, California;

Plank, Donald L., University of Rochester;

Porter, Lawrence D., New York University;

Press, Sheldon J., Stanford University;

Prillo, Anthony A. J., Loyola College, Montreal, Quebec, Canada;

Quennet, Jean, Societe Nationale des Chemins de fer français-Bibliothèque, Paris $9^{\circ}$, France;

Rau, John G., North American Aviation Corporation, Anaheim, California;

Ray, Thomas L., Esso Research, Madison, New Jersey;

Ray-Chaudhuri, Dwijendra K., Thomas J. Watson Research Center, International

Business Machines Corporation, Yorktown Heights, New York;

Reed, Robert B., University of Waterloo;

Reily, Dean M., Engineering Physics Company, Rockville, Maryland;

Richardson, Edward H., University of Tennessee;

Riddiford, Alan W., Harvard University;

Robinson, Stanley F., Pasadena City College;

Rogers, Fred N., Washington University;

Rolando, Josefina G. (Mrs.), Merrimack College;

Rosenzweig. Harrv L.. Universitv of Virginia: 
Schay, Geza, The George Washington University;

Schmeltzer, Dr. Robert A., Bell Telephone Laboratories, Holmdel, New Jersey;

Schulenberger, John R., University of Arizona;

Schulz, Raymond H., P. O. Box 35, White Sands Missile Range, New Mexico 88002;

Sheets, Marion S., Continental Carbon Company, Houston, Texas;

Sinauer, Donald, 4 Seymour Place, White Plains, New York 10605;

Sister Mary Hugh McKillop, St. Xavier College;

Smith, Duane B., Orlando Data Center, Orlando, Florida;

Smith, James C., Jr., College of William and Mary;

Smith, Sanford O., Stetson University;

Snow, Douglas O., Acadia University;

Sperry, Paul L., University of South Carolina;

Sterling, Nicholas J., Jr., Syracuse University;

Stubbs, Robert T., Armstrong College;

Stumpf, Luis W., Aeronutronic, Newport Beach, California;

Stumpf, Werner E., International Business Machines Corporation, Poughkeepsie, New York;

Sudler, Culbreth Jr., Box 24624, Los Angeles, California 90024;

Sulski, Leonard C., University of Notre Dame;

Susanta, Bernardus, Gadjah Mada University, Jogjakarta, Indonesia;

Thomas, Thomas J., Nortronics, Anaheim, California;

Toralballa, Leopoldo C., Princeton University;

Travers, Arlyne R., Curtiss-Wright Corporation, Caldwell, New Jersey;

Ullrich, David F., Carnegie Institute of Technology;

Uppuluri, Venkata Ramamohana R., Oak Ridge National Laboratory, Oak Ridge, Tennessee 37831;

Vebber, Robert J., Motorola, Incorporated, Scottsdale, Arizona;

Waldhart, Neil A., TRW Space Technology Laboratories, Incorporated, Redondo Beach, California;

Walenga, John R., DeVry Technical Institute;

Wallace, Charles R., General Electric Company, Huntsville, Alabama;

Walton, William E., United Gas Corporation, Shreveport, Louisiana;

Wells, Benjamin F., III, University of California, Berkeley;

White, Reginald, Boeing Company, New Orleans, Louisiana;

Williams, Richie D., Ft. Valley State College;

Wineman, Alan S., Brown University;

Winter, Mary K., Northwestern University;

Wise, Clifford A., Rugby College of Engineering Technology, Eastlands, Rugby, Warwickshire, England;

Wong, Eugene, University of California, Berkeley;

Wong, James S. W., University of Alberta, Edmonton, Alberta, Canada;

Woythaler, Joseph W., Curtiss-Wright (VTOL), Caldwell, New Jersey;

Yang, Chao-Hui, 140 Montgomery Street, Highland Park, New Jersey;

Yates, Charles M., Cornell University;

Yee-Fan, Aerojet-General Corporation, Sacramento, California;

Zajac, Edward E., Bell Telephone Laboratories, Incorporated, Murray Hill, New Jersey;

Zerla, Fredric J., University of South Florida; 
It was announced that the following had been admitted to the Society in accordance with reciprocity agreements with various mathematical organizations:

Wiskundig Genootschap te Amsterdam: Morimus A. Kaashoek, Frans Van Scheepen. Union Matematica Argentina: German Fernandez.

Australian Mathematical Society: Joseph M. Gani.

Dansk Matematisk Forening: Anders Bager.

The London Mathematical Society: Shing Kit Hsu, Peter G. Lowe.

Société Mathématique de France: Janos D. Aczel, Jean Bass, Jean J. Benabou, Bray

Georges, Alfredo P. Gomes, Luc Illusie, Max Karoubi, Artibano Micali.

Suomen Matemaattinen Yhdistys: Olli K. Jussila.

Deutsche Mathematiker Vereinigung: Egbert Harzheim, Wilhelm Kaup, Horst F.

Niemeyer, Helmut R. Salzmann, Heinz Schoneborn, Karlheinz Spallek.

Gesellschaft für Angewandte Mathematik und Mechanik: H. Behrbohm.

Indian Mathematical Society: Shrin Bhatt, Sampuran S. Cheema, Deva C. Doss,

Tej N. Sinha.

Israel Mathematical Union: Reuben R. Rottenberg.

Mathematical Society of Japan: Yutaka Ando, Hiroaki Hijikata, Yasutaka Ihara,

Tadashige Ishihara, Ohashi Kempachiro, Hirobuni Mizuno, Keio Nagami,

Makiko Nisio, Masaru Takeuchi, Nakamura Tokushi.

Svenska Matematikersamfunder: Hans E. Wallin.

The following thirty-nine persons have been elected to membership in the Society on nomination of institutional members as indicated:

Antioch College: Tanya Mink, Lawrence D. Stone.

University of Arizona: Eugene V. Sherman.

Brown University: William T. Kiley, Ernst A. Ruh.

Catholic University of America: Brother Franz Kiesler.

Central Michigan University: Joseph F. Csendes.

Eastern New Mexico University: Jack A. Howard, W. Barry Morgan, Robert M. Nelson.

Harvard University: John C. Fogarty, Herbert M. Gintis, Richard A. Holzsager, Daniel G. Quillen.

Hobart and William Smith Colleges: Robert E. Lamberson, Abigail M. Mosey, Philip E. Reed.

New Mexico State University: Ralph W. Ball, Adolph G. Mader.

University of Notre Dame: James F. Slifker, Donald R. Weidman.

Oakland University: James P. Bouhana, Dianne C. Greene, Maryann P. Maledon.

Oklahoma State University: William A. Glynn, William A. Thedford, Forrest D. Whitfield.

Oregon State University: Gary J. Ford, Allen R. Freedman, Jack S. Zelver.

University of Pennsylvania: Chelyanayakam Vaseekaran.

State University of New York at Stony Brook: John K. Stutz.

Tulane University: Raymond J. Cannon, Jr., Justin T. Lloyd, Donald E. Ramirez, Charles T. Scarborough, Jr., Maxwell E. Shauck, Jr. 
U. S. Air Force Academy: Capt. Kenneth E. Brant.

Western Washington State College: Edmund P. Geyer.

The following Presidential appointments were reported:

As a Committee to Nominate the Winner of the Cole Prize in Algebra: Maxwell Rosenlicht, Chairman, Nathan Jacobson, and Hans Zassenhaus.

Philip J. McCarthy to the Advisory Committee for the Mathematical and Statistical Section of the National Register.

J. Paul Roth to represent the Society at the inauguration of Alan Simpson as President of Vassar College.

The following have accepted invitations to deliver hour addresses: Jun-ichi Igusa at the October, 1964 meeting at Adelphi University; Eugenio Calabi and D. H. Mumford at the Annual Meeting in Denver in January, 1965.

The Council voted to recommend to the Board of Trustees that, subject to the concurrence of the National Research Council, the Society take over on a permanent basis the journal Mathematics of Computation.

The Council approved a proposal by the Trustees that Annual dues be raised to twenty dollars in 1966, and ordered the appropriate changes in the by-laws to be introduced at the Business Meeting at the Annual Meeting in January, 1965.

It was approved to continue holding for another two year period the special sessions for twenty-minute papers at Annual Meetings.

The Editorial Committee for the Transactions was increased from five to six because of the large increase in the number of papers received in logic.

There was a Business Meeting at 10:30 A.M., Thursday, August 26. President Doob presided and expressed appreciation on behalf of the Society for the hospitality extended to the mathematical organizations by the University of Massachusetts. He then presented Dr. Fred Armstrong of the U. S. Steel Foundation, which had generously contributed ten thousand dollars toward the support of the 1964 Summer Institute in Algebraic Geometry, with a bound copy of the lecture notes from the Institute.

The Secretary reported briefly on the affairs of the Society and Council actions. Mr. Herman Rubin brought up from the floor the question of whether the number of ten-minute papers at the present meeting should have been limited when there was apparently a vacant afternoon on the program. Associate Secretary Everett Pitcher pointed out that the afternoon in question was not actually vacant 
but set aside for certain portions of the Association Program, with which, by agreement, the Society does not conflict. Also he pointed out that the number of papers submitted for the present meeting was less than the number set down as an upper limit.

The Meeting adjourned at 11:00.

JoHn W. Green, Secretary

Everett Pitcher, Associate Secretary

Los Angeles, California

Bethlehem, Pennsylvania 